\title{
Hemilabile P,O-Ligands in Palladium Catalysed C-C Linkages: Codimerization of Ethylene and Styrene and Cooligomerization of Ethylene and Carbon Monoxide
}

George J. P. Britovsek, a Wilhelm Keim,*a Stefan Mecking, a Daniel Sainz ${ }^{b}$ and Trixie Wagner ${ }^{c}$

a Institut für Technische Chemie, RWTH Aachen, Worringer Weg 1, D-52074 Aachen, Germany

- Departament de Química Inorgànica, Universitat de Barcelona, Spain

c Institut für Anorganische Chemie, RWTH Aachen, Prof.-Pirlet-Str. 1, D-52074 Aachen, Germany

Neutral and cationic palladium allyl complexes with bidentate ligands $\mathrm{Ph}_{2} \mathrm{P}\left(\mathrm{CH}_{2}\right)_{n} \mathrm{CO}_{2}-(n=1-3 ; X$-ray crystal structure determination for complexes with $n=1$ and 2$)$ or $\mathrm{Ph}_{2} \mathrm{P}\left(\mathrm{CH}_{2}\right)_{n} \mathrm{CO}_{2} \mathrm{R}(n=1-3 ; \mathrm{R}=\mathrm{Me}$, Et) have been prepared and used as catalysts for the codimerization of ethylene and styrene and for the cooligomerization of ethylene and carbon monoxide.

Bidentate P,O-ligands, combining a hard and a soft donor atom, show interesting properties in coordination chemistry and catalysis. ${ }^{1}$ Depending on the strength of the P-metal or $\mathrm{O}$-metal bonds the equilibria shown in eqn. (1) can exist, in which the ligand bite opens up.

$$
\left.L_{n} M_{-}^{-P}=L^{P} \rightleftharpoons M_{-O}^{-P}\right) \rightleftharpoons L_{n} M_{-O}^{-D} P
$$

This opening of the chelate bite can be initiated by other ligands or solvent molecules and has been termed hemilabile. 
Chelating anionic P,O-ligands are successfully applied in the nickel-catalysed oligomerization of ethylene in the Shell higher olefin process. ${ }^{2}$ The question arises: can this chemistry be transferred to palladium?

We have prepared novel neutral and cationic palladium allyl complexes with $\omega$-(diphenylphosphino)carboxylates or $\omega$-(diphenylphosphino) carboxylic acid esters as ligands (Scheme 1) and investigated their catalytic properties for the C-C linkage of ethylene with styrene ${ }^{3}$ or carbon monoxide. ${ }^{4}$

Compounds 1-7 were characterized by ${ }^{1} \mathrm{H}, \dagger{ }^{13} \mathrm{C} \dagger$ and ${ }^{31} \mathrm{P}$ NMR and IR spectroscopy (Table 1). Coordination of the ester function in compounds 4-6 via the carbonyl oxygen-atom is supported by the decrease of $v(\mathrm{CO})$ of about $80 \mathrm{~cm}^{-1}$

Table $1{ }^{31} \mathrm{P}$ NMR and IR spectroscopic data of complexes and ligands

\begin{tabular}{|c|c|c|}
\hline Compound & ${ }^{31} \mathrm{P}\left\{{ }^{1} \mathrm{H}\right\} \mathrm{NMR} / \delta$ & $\begin{array}{l}\mathrm{IR}^{c} v(\mathrm{CO}) \text { resp. } \\
v\left(\mathrm{CO}_{2}\right)_{\mathrm{asym}} / \mathrm{cm}^{-1}\end{array}$ \\
\hline 1 & $+14.2^{a}$ & 1632 \\
\hline 2 & $+25.5^{a}$ & 1607 \\
\hline 3 & $+21.4^{a}$ & 1599 \\
\hline 4 & $+21.7^{b}$ & 1638 \\
\hline 5 & $+22.6^{b}$ & 1655 \\
\hline 6 & $+15.2^{b}$ & 1647 \\
\hline 7 & $+19.1^{b}$ & 1730 \\
\hline $\mathrm{Ph}_{2} \mathrm{P}\left(\mathrm{CH}_{2}\right)_{n} \mathrm{CO}_{2} \mathrm{H}^{d}$ & $-15.2--16.3^{a}$ & $1703 ; 1711 ; 1709$ \\
\hline $\mathrm{Ph}_{2} \mathrm{P}\left(\mathrm{CH}_{2}\right)_{n} \mathrm{CO}_{2} \mathrm{R}^{e}$ & $-15.0--16.1^{a}$ & $1728-1730$ \\
\hline
\end{tabular}

${ }^{a} \mathrm{CDCl}_{3} .{ }^{b} \mathrm{CH}_{2} \mathrm{Cl}_{2}-\mathrm{CD}_{2} \mathrm{Cl}_{2}$. ${ }^{c} \mathrm{CH}_{2} \mathrm{Cl}_{2}$ solution. ${ }^{d} n=1 ; 2 ; 3$. ${ }^{e} n=1$, $\mathrm{R}=\mathrm{Me} ; n=2, \mathrm{R}=\mathrm{Et} ; n=3, \mathrm{R}=\mathrm{Et}$.

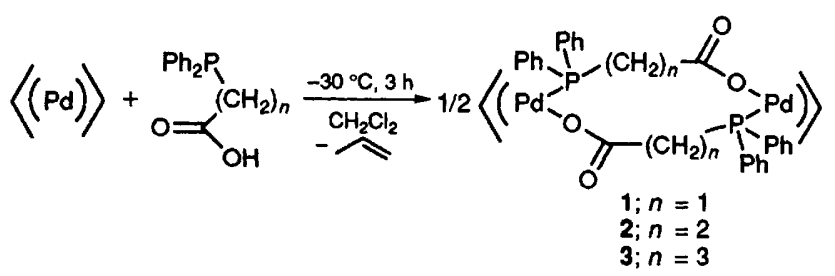

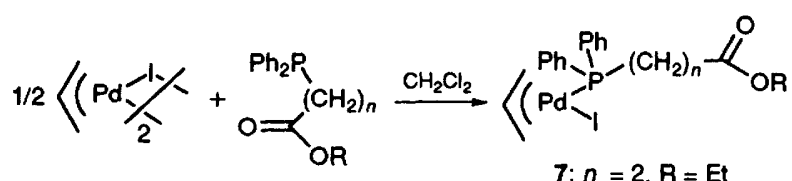
$7 ; n=2, R=E t$ $\underset{\mathrm{CH}_{2} \mathrm{Cl}_{2}}{5} \mid \begin{aligned} & +\mathrm{AgSbF}_{6} \\ & -\mathrm{Agl}\end{aligned}$ $\left[\left\langle\left(\mathrm{Pd}_{\mathrm{O}}^{\mathrm{Ph}}==_{\mathrm{OR}}^{\mathrm{Ph}}-\left(\mathrm{CH}_{2}\right)_{n}\right]^{+} \mathrm{SbF}_{6}^{-}\right.\right.$ 4; $n=1, R=M_{\theta}$ $5 ; n=2, R=E t$ 6; $n=3, R=E$

Scheme 1 Synthesis of palladium complexes

$\dagger$ Representative NMR data of complexes 2 and $5(n=2)$. Numbering of the allyl-atoms: $\mathrm{H}^{1}($ syn $) \mathrm{H}^{2}$ (anti) $\mathrm{C}^{1}-\mathrm{C}^{2} \mathrm{H}^{5}-\mathrm{C}^{3} \mathrm{H}^{4}($ syn $) \mathrm{H}^{3}$ (anti), $\mathrm{C}^{1}$ is trans to P. Complex 2: ${ }^{1} \mathrm{H}$ NMR $\left(\mathrm{CDCl}_{3}, 200 \mathrm{MHz}\right) \delta 7.3-7.7(\mathrm{~m}, 10$ $\mathrm{H}$, arom.), 5.49-5.69 (m, $\left.1 \mathrm{H}, \mathrm{H}^{5}\right), 4.82\left(\mathrm{t},{ }^{3} J_{\mathrm{HH}}={ }^{3} J_{\mathrm{PH}} 7 \mathrm{~Hz}, 1 \mathrm{H}\right.$, $\left.\mathrm{H}^{1}\right), 3.90\left(\mathrm{dd},{ }^{3} J_{\mathrm{HH}} 14 \mathrm{~Hz},{ }^{3} J_{\mathrm{PH}} 9 \mathrm{~Hz}, 1 \mathrm{H}, \mathrm{H}^{2}\right), 3.0\left(\mathrm{br} \mathrm{s}, 1 \mathrm{H}, \mathrm{H}^{4}\right)$, $2.2-2.7\left(\mathrm{~m}, 5 \mathrm{H}, \mathrm{CH}_{2} \mathrm{CH}_{2}\right.$ and $\left.\mathrm{H}^{3}\right) .{ }^{13} \mathrm{C}\left\{{ }^{1} \mathrm{H}\right\} \mathrm{NMR}\left(\mathrm{CDCl}_{3}, 50 \mathrm{MHz}\right) \delta$ $176.9\left(\mathrm{~d},{ }^{3} J_{\mathrm{PC}} 8 \mathrm{~Hz}, \mathrm{CO}\right), 128.9-132.8\left(\mathrm{C}_{\text {arom }}\right), 118.3\left(\mathrm{C}^{2}\right.$ allyl $), 82$ (br, $\left.\mathrm{C}^{1}{ }_{\text {allyl }}\right), 47.9\left(\mathrm{C}^{3}\right.$ allyl $), 31.9\left(\mathrm{C}^{\alpha}\right), 23.5\left(\mathrm{~d},{ }^{1} J_{\mathrm{PC}} 25 \mathrm{~Hz}, \mathrm{C}^{\beta}\right)$.

Complex 5: ${ }^{1} \mathrm{H}$ NMR $\left(\mathrm{CD}_{2} \mathrm{Cl}_{2}, 200 \mathrm{MHz}\right) \delta 7.5-7.8(\mathrm{~m}, 10 \mathrm{H}$, arom. $), 5.84-6.05\left(\mathrm{~m}, 1 \mathrm{H}, \mathrm{H}^{5}\right), 5.16\left(\mathrm{t},{ }^{3} J_{\mathrm{HH}}={ }^{3} J_{\mathrm{PH}} 7 \mathrm{~Hz}, 1 \mathrm{H}, \mathrm{H}^{1}\right)$, $4.37\left(\mathrm{q},{ }^{3} J_{\mathrm{HH}} 7 \mathrm{~Hz}, 2 \mathrm{H}, \mathrm{OCH}_{2}\right), 4.29\left(\mathrm{dd},{ }^{3} J_{\mathrm{HH}} 14 \mathrm{~Hz},{ }^{3} J_{\mathrm{PH}} 8 \mathrm{~Hz}, 1 \mathrm{H}\right.$, $\left.\mathrm{H}^{2}\right), 3.7\left(\mathrm{br} \mathrm{s}, 1 \mathrm{H}, \mathrm{H}^{4}\right), 2.5-3.0\left(\mathrm{~m}, 5 \mathrm{H}, \mathrm{CH}_{2} \mathrm{CH}_{2}\right.$ and $\left.\mathrm{H}^{3}\right), 1.35(\mathrm{t}$, $\left.{ }^{3} J_{\mathrm{HH}} 7 \mathrm{~Hz}, 3 \mathrm{H}, \mathrm{CH}_{3}\right),{ }^{13} \mathrm{C}\left\{{ }^{1} \mathrm{H}\right\} \mathrm{NMR}\left(\mathrm{CH}_{2} \mathrm{Cl}_{2}-\mathrm{CD}_{2} \mathrm{Cl}_{2}, 50 \mathrm{MHz}\right) \delta$ $180.9(\mathrm{CO}), 130.0-133.1\left(\mathrm{C}_{\text {arom }}\right), 121.8\left(\mathrm{~d},{ }^{2} J_{\mathrm{PC}} 5 \mathrm{~Hz}, \mathrm{C}^{2}\right.$ allyl $), 88.2(\mathrm{~d}$, $\left.{ }^{2} J_{\mathrm{PC}} 26 \mathrm{~Hz}, \mathrm{C}^{1}{ }_{\text {allyl }}\right), 65.8\left(\mathrm{OCH}_{2}\right), 50.5\left(\mathrm{C}^{3}{ }_{\text {ally }}\right), 29.3\left(\mathrm{C}^{\alpha}\right), 20.8\left(\mathrm{~d},{ }^{1} J_{\mathrm{PC}}\right.$ $\left.25 \mathrm{~Hz}, \mathrm{C}^{\beta}\right), 13.9\left(\mathrm{CH}_{3}\right)$ compared with the uncoordinated ester function in the ligand or in complex 7.5 Complexes 1 and 2 are dimeric in the solid state. X-Ray crystal structure analyses $\$$ show, that the two
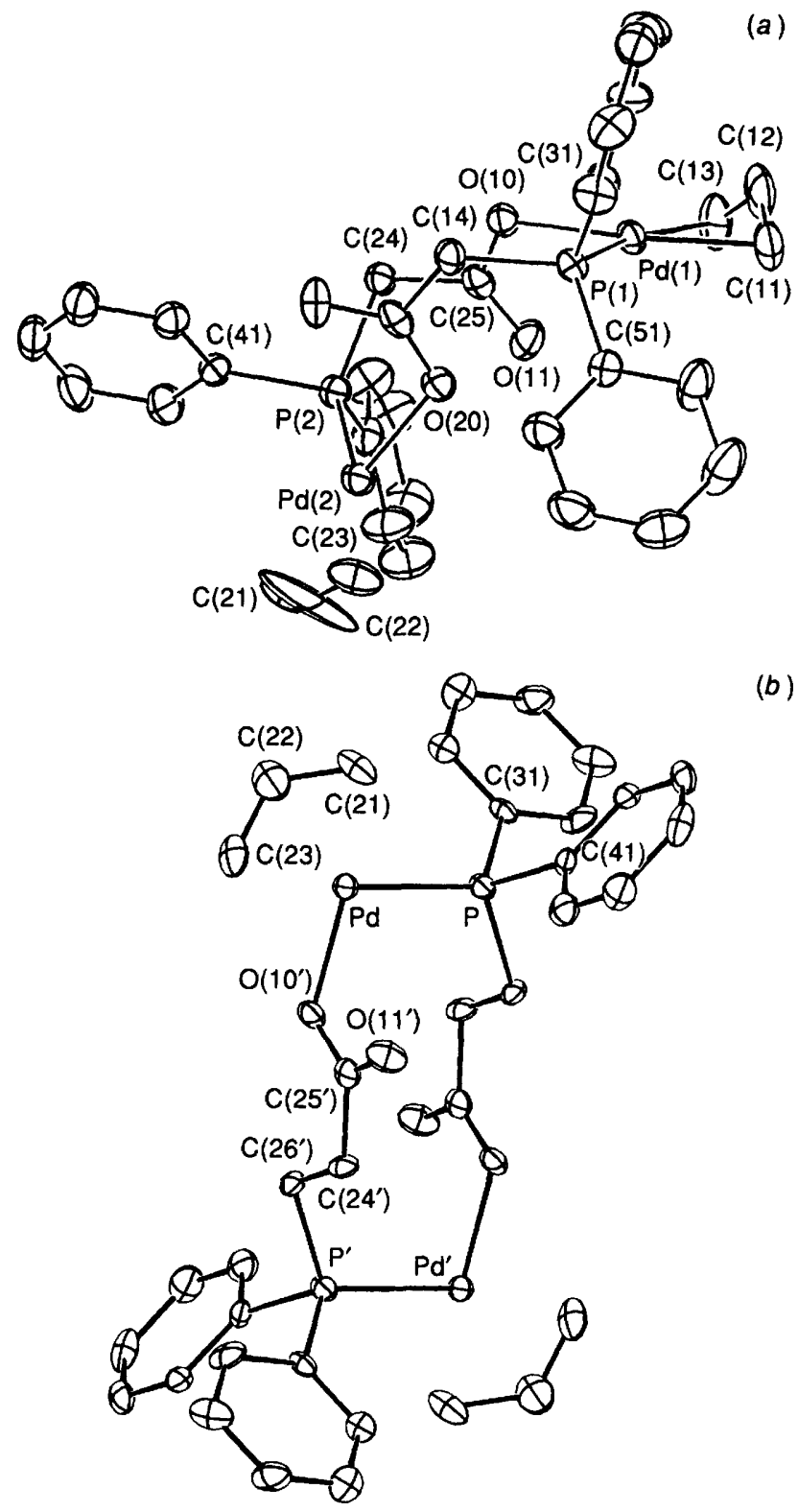

(b)

Fig. 1 Structure of complexes $1(a)$ and $2(b)$. Selected bond lengths $(\AA \AA)$ and angles $\left({ }^{\circ}\right)$ for 1: $\mathrm{Pd}(1)-\mathrm{P}(1)$ 2.293(2), $\mathrm{Pd}(1)-\mathrm{O}(10) 2.093(3)$, $\operatorname{Pd}(1)-C(11) 2.107(6), \operatorname{Pd}(1)-C(12) 2.137(7), P d(1)-C(13) 2.215(7)$, $\mathrm{C}(11)-\mathrm{C}(12) \quad 1.37(1), \quad \mathrm{C}(12)-\mathrm{C}(13) \quad 1.39(1), \quad \mathrm{P}(1)-\mathrm{Pd}(1)-\mathrm{O}(10)$ 92.1(1), C(11)-Pd(1)-C(13) 67.9(3).

$\ddagger$ Crystal data: Crystals suitable for $\mathrm{X}$-ray diffraction were obtained from $\mathrm{CH}_{2} \mathrm{Cl}_{2}$-pentane solutions.

For 1: $\mathrm{C}_{34} \mathrm{H}_{34} \mathrm{O}_{4} \mathrm{P}_{2} \mathrm{Pd}_{2} \cdot 2 \mathrm{CH}_{2} \mathrm{Cl}_{2}, M=951.26,6669$ reflections $\left(3^{\circ}<\right.$ $\theta<24^{\circ}$ ) collected at $298 \mathrm{~K}$ on an Enraf-Nonius CAD4 diffractometer, monoclinic, space group $P 2_{1} / n$ (No. 14), $a=12.757(2), b=24.045(8)$, $c=13.035(3) \AA, \beta=100.08(2)^{\circ}, U=3937(3) \AA^{3}, Z=4, D_{c}=1.605$ $\mathrm{g} \mathrm{cm}^{-1}$; Mo-K $\alpha$ radiation, $\lambda=0.7093 \AA, \mu=12.91 \mathrm{~cm}^{-1}$, final $R=$ $0.044\left(R_{\mathrm{w}}=0.052\right)$ for 4047 independent reflections $[I>2 \sigma(I)], 433$ parameters.

For 2: $\mathrm{C}_{36} \mathrm{H}_{38} \mathrm{O}_{4} \mathrm{P}_{2} \mathrm{Pd}_{2} \cdot 2 \mathrm{CH}_{2} \mathrm{Cl}_{2}, M=979.32,3396$ reflections $\left(3^{\circ}<\right.$ $\theta<25^{\circ}$ ) collected at $248 \mathrm{~K}$, triclinic, space group $P \overline{1}$ (No. 2$), a=$ 9.770(1), $b=10.039(2), c=10.455(2) \AA, \alpha=93.78(2), \beta=95.47(1)$, $\gamma=95.60(1)^{\circ}, U=1013(1) \AA^{3}, Z=1, D_{\mathrm{c}}=1.605 \mathrm{~g} \mathrm{~cm}^{-1}$; Mo-K $\alpha$ radiation, $\lambda=0.7107 \AA, \mu=12.57 \mathrm{~cm}^{-1}$, final $R=0.068\left(R_{\mathrm{w}}=0.069\right)$ for 2140 independent reflections $[I>2 \sigma(I)], 226$ parameters.

Atomic coordinates, bond lengths and angles, and thermal parameters have been deposited at the Cambridge Crystallographic Data Centre. See Notice to Authors, Issue No. 1. 
palladium centres are bridged by the $\mathrm{P}, \mathrm{O}$-ligands (Fig. 1), the allyl-substituents are asymmetrically $\eta^{3}$-bonded and the carboxylate groups are unidentately coordinated. ${ }^{6}$ Bond lengths and angles are unexceptional.

The chain length $n$ of the ligand has no dramatic effect in the following catalytic reactions. $\$(i)$ Oligomerization of ethylene: the neutral complexes 1-3 show very little activity in ethylene oligomerization. Less than $5 \%$ conversion to butenes and hexenes are observed at $110^{\circ} \mathrm{C}$. The cationic complexes 4-6 are very active for the conversion of ethylene to butenes ${ }^{7}(e . g$. turn over numbers, TONף $=4100$ with complex 5 ; reaction time $1.5 \mathrm{~h}$ at $50^{\circ} \mathrm{C} ; 82 \%$ conversion). In this experiment a ratio but-1-ene : but-2-enes of $6: 94$ was obtained.

(ii) Codimerization of ethylene and styrene: the cationic complexes 4-6 are also very active for the codimerization of ethylene with styrene. 3-Phenylbut-1-ene is observed as the main product besides $(E)$ - and $(Z)$-2-phenylbut-2-ene and butenes $(e . g$. TON $=270$ with complex 4; reaction time $1 \mathrm{~h}$ at room temperature; conversion of styrene $68 \%$ with $75 \%$ selectivity to 3-phenylbut-1-ene). At higher conversions further isomerization to the internal olefins occurs.

(iii) Cooligomerization of ethylene and carbon monoxide: the neutral complexes 1-3 show only moderate activity for formation of alternating polyketone (TON around 150 at $110^{\circ} \mathrm{C}$ ). However, the cationic complexes 4-6 yield alternating polyketones with TON up to 800 at $50^{\circ} \mathrm{C}$. Interestingly, at high ethylene to $\mathrm{CO}$ ratios $(\mathrm{m} / \mathrm{m}=10: 1)$ ethylvinylketone (4||), 1- and 2-hepten-5-ones (35), oct-1-en-3,6-dione (3), 1-

$\S$ General conditions: $0.03-0.1 \mathrm{mmol}$ of complex dissolved in $20 \mathrm{ml}$ $\mathrm{CH}_{2} \mathrm{Cl}_{2} ; p\left(\mathrm{C}_{2} \mathrm{H}_{4}\right)=10-30$ bar; optionally $p(\mathrm{CO})=5-30$ bar or $2 \mathrm{ml}$ styrene; reaction time $1-65 \mathrm{~h}$.

I Turn over numbers are given as mol of substrate converted per mol of palladium during the entire experiment.

\| A typical product distribution (mass ratios) is given in parentheses (obtained with complex 5; reaction time $16 \mathrm{~h}$ at $50{ }^{\circ} \mathrm{C}$; TON $=414$; complete conversion of $\mathrm{CO}$ ). Depending on reaction conditions, the 1 - or the 2 -isomers can predominate. and 2-decen-5,8-diones (7) and higher alternating cooligomers and polymers (100) with an ethyl and a vinyl or butenyl end group are obtained. 8

The above experiments show a dramatic effect for anionic vs. neutral $\mathrm{P}, \mathrm{O}$-ligands. We speculate that this difference is due to the hemilabile behaviour of the $\mathrm{CO}_{2} \mathrm{R}$-group as shown in eqn. (1). Under catalytic conditions the O-Pd bond in 4-6 dissociates, thus generating free coordination sites for catalysis.

We are grateful to BP Chemicals for financial support and to DEGUSSA AG for a generous loan of palladium chloride.

\section{References}

1 A. Bader and E. Lindner, Coord. Chem. Rev., 1991, 108, 27

2 W. Keim, Angew. Chem., Int. Ed. Engl., 1990, 29, 235.

3 G. Wilke, Angew. Chem., Int. Ed. Engl., 1988, 27, 185; S. Hattori, H. Munakata, K. Tatsuoka and T. Shimizu, US Pat., 3803254 , 1974.

4 E. Drent, Eur. Pat. Appl., 121 965, 1984; E. Drent, J. A. M. van Broekhoven and M. J. Doyle, J. Organomet. Chem., 1991, 417, 235; Z. Jiang, G. M. Dahlen, K. Houseknecht and A. Sen, Macromolecules, 1992, 25, 2999 and references cited therein.

5 P. Braunstein, D. Matt, Y. Dusausoy, J. Fischer, A. Mitschler and L. Ricard, J. Am. Chem. Soc., 1981, 103, 5115; P. Braunstein, D. Matt and Y. Dusausoy, Inorg. Chem., 1983, 22, 2043.

6 For the structurally related (monomeric) compound $\left[\left(o-\mathrm{C}_{6} \mathrm{H}_{4} \mathrm{CH}_{2} \mathrm{NMe}_{2}\right)^{P} d\left\{\mathrm{Ph}_{2} \mathrm{PCH}_{2} \mathrm{C}(\mathrm{O}) \mathrm{O}\right\}\right]$ see P. Braunstein, D. Matt, D. Nobel, S.-E. Bouaoud and D. Grandjean, J. Organomet. Chem., 1986, 301, 401.

7 Similar results have been described with other cationic palladium complexes: A. Sen and T.-W. Lai, J. Am. Chem. Soc., 1982, 104, 3520 .

8 For other transition-metal catalysed cooligomerizations of ethylene and CO see A. Sen, J. S. Brumbaugh and M. Lin, J. Mol. Catal., 1992, 73, 297; J. D. McClure, Ger. Offen., DE 2046 060, 1971 and Ger. Offen., DE $2054307,1971$. 